\title{
Työntekijän altistuminen pölyille ja kaasuille suuressa pihattonavetassa
}

\author{
Jukka Mäittälä, Kyösti Louhelainen, Outi Lankia ja Juhani Kangas \\ Työterveyslaitos, PL 93,70701 Kuopio, jukka.maittala@ttl.fi
}

\section{Johdanto}

Maataloudessa on tapahtunut Euroopan yhteisöön liittymisen jälkeen suuria muutoksia. Liittyminen Euroopan yhteiseen maatalouspolitiikkaan merkitsi siirtymistä tuotantomääriin perustuvasta maataloustukijärjestelmästä viljelyalaan ja eläinyksikköihin perustuvaan tukijärjestelmään. Tämä muutti merkittävästi maatalouden toimintaedellytyksiä ja asetti paineita tilakoon jatkuvaan kasvattamiseen. Tilakoon kasvun myötä työmäärä on lisääntynyt. Lypsykarjatiloilla on vähitellen siirrytty parsinavetoista pihattotyyppisiin tuotantorakennuksiin. Tämä on monin tavoin muuttanut työympäristöä ja -menetelmiä. Onko työntekijän altistuminen ilman epäpuhtauksille muuttunut rakennemuutoksen myötä?

Maataloustyöntekijät altistuvat työssään monille kemiallisille, fysikaalisille ja biologisille haittatekijöille. Kemiallisia haittoja aiheuttavat esimerkiksi orgaaniset pölyt, pesu- ja desinfiointiaineet sekä kaasumaiset yhdisteet. Viljelijöillä ja lomittajilla yleisiä sairauksia ovat allerginen nuha, astma, krooninen keuhkoputkentulehdus ja allerginen alveoliitti (homepölykeuhko). Yleisiä hengitystieoireita viljelijöiden keskuudessa ovat vinkuva hengitys, hengenahdistus ja yskä, mitkä ovat verrattain epäspesifisiä ja ne voidaan liittää useisiin työperäisiin hengityselinsairauksiin.

Kuopion aluetyöterveyslaitoksella toteutettiin vuosina 2002-2003 tutkimus, jossa arvioitiin viljelijän työympäristöä ja kuormittumista suurnavetassa. Fyysisen ja henkisen kuormittumisen ohella tutkittiin viljelijän altistumista erilaisille pölyille, kaasuille, melulle ja lämpöoloille. Tässä kirjoituksessa keskitytään hengittyvän pölyn sekä ammoniakin ja hiilidioksidin pitoisuuksiin ja niiden aiheuttamaan altistumiseen navetan iltatöiden aikana.

\section{Aineisto ja menetelmät}

Tutkimuksessa oli mukana 20 keskisuurta tai suurta pihattoa Keski-Pohjanmaalta ja Pohjois-Savosta. Pihatot oli rakennettu tai peruskorjattu vuosina 1995-2001. Kokonaan uusia (alle 10 vuotta vanhoja) tuotantorakennuksia oli kahdeksan. Myös uusia tuotantorakennuksia oli ehditty laajentaa, muutamia useita kertoja. Peruskorjatuista vanhoista tuotantorakennuksista navetta oli useimmiten peruskorjattu siten, että lypsylehmille oli rakennettu uusi pihatto-osasto ja hiehot ja muu nuorkarja olivat vanhassa parsinavetassa.

Tilakäyntien alkaessa yhdellä tilalla oli käytössä lypsyrobotti. Tilakäyntien loppuessa lypsyrobotti oli hankittu neljälle tilalle. Lypsyaseman koko vaihteli kuudesta kuuteentoista lehmäpaikkaan. Lypsyssä olevia lehmiä oli keskimäärin 54 ja keskituotos oli 8100. Kaikissa pihatoissa yhtä lukuun ottamatta lanta käsiteltiin lietelantana. Useimmissa pihatoissa käytettiin kuivikkeita. Yleisin kuivike oli kutterinpuru lehmillä ja olki vasikoilla. Myös turvetta käytettiin jonkin verran lypsylehmien ja hiehojen kuivikkeena.

Hengittyvä pöly kuvaa työntekijän hengitysteihin pääsevää osuutta työympäristön ilmassa leijuvasta orgaanisen ja epäorgaanisen pölyn kokonaismäärästä. Pihaton ilman hengittyvän pölyn pitoisuudet määritettiin kahdesta kiinteästä mittauspisteestä ruokintakäytävältä ja lypsyasemalta. Kiinteiden mittauspisteiden lisäksi kerättiin pölynäytteet työntekijöiden hengitysvyöhykkeeltä. Tutkitut työvaiheet olivat lypsytyö sekä karjanhoitajan työ, joka sisälsi muun muassa parsien puhdistamista ja kuivittamista, lypsyssä avustamista, nuorkarjan ruokkimista ja lypsyaseman painepesua. Pölynäytteet kerättiin näytteenottopumpulla IOM-keräimen selluloosa-asetaattisuodattimelle. Näytteiden pölypitoisuudet määritettiin gravimetrisesti. Tulokset ilmoitetaan yksikössä $\mathrm{mg} / \mathrm{m}^{3}$.

Navettailman ammoniakki- ja hiilidioksidipitoisuus määritettiin suoraanosoittavalla diffuusioputkella. Putket sijoitettiin ruokintakäytävälle, lypsyasemalle ja lietelantakanaviin ritilöiden alapuolelle. Näytteenottoaika oli muutama tunti, jonka jälkeen pitoisuus $\left(\mathrm{cm}^{3} / \mathrm{m}^{3}\right.$ eli miljoonasosaa (ppm)) luettiin välittömästi putken pitoisuusasteikolta. 


\section{Tulokset ja tulosten tarkastelu}

Hengittyvän pölyn pitoisuudet on esitetty kuvassa 1 . Keskimäärin pihaton ilman pölypitoisuus jäi kymmeneen prosenttiin orgaanisen pölyn haitalliseksi tunnetusta pitoisuudesta $\left(\mathrm{HTP}_{8 \mathrm{~h}} 5 \mathrm{mg} / \mathrm{m}^{3}\right)$. Työntekijöiden henkilökohtainen altistuminen oli 20-30 prosenttia ohjearvosta. Yksi hengitysvyöhykenäyte ylitti orgaanisen pölyn HTP-arvon. Keväällä 2003 keskimääräiset pitoisuudet olivat alhaisempia kuin syksyllä 2002.

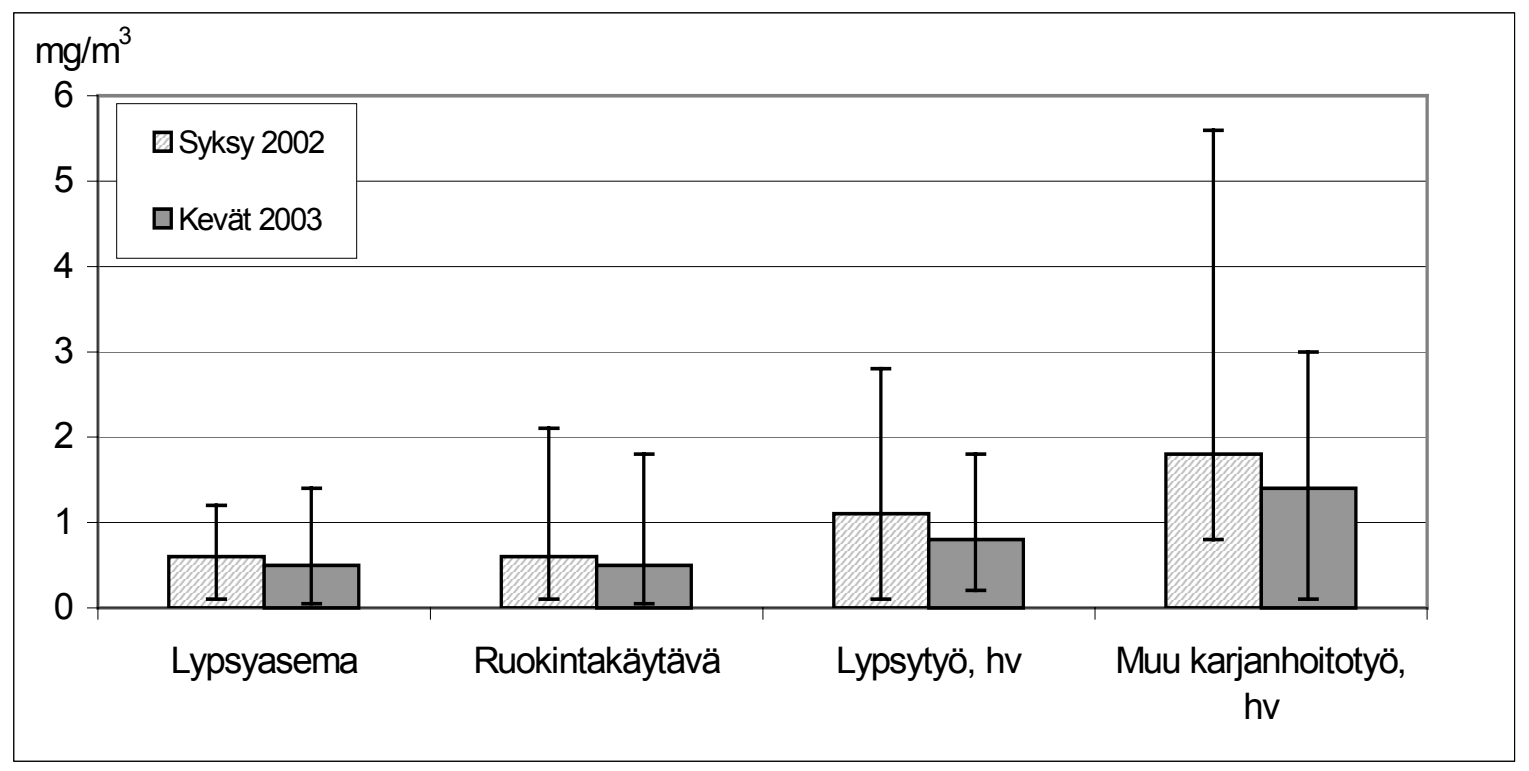

Kuva 1. Hengittyvän pölyn aritmeettiset keskiarvot ja vaihteluvälit $\left(\mathrm{mg} / \mathrm{m}^{3}\right) . \mathrm{hv}=$ hengitysvyöhyke

Lypsytyötä tekevän altistuminen hengittyvälle pölylle vaihteli $<0,1-2,8 \mathrm{mg} / \mathrm{m}^{3}$ ja muita karjanhoitotöitä tekevän altistumisen vaihteluväli oli $0,8-5,6 \mathrm{mg} / \mathrm{m}^{3}$. Suurin hengittyvän pölyn pitoisuus mitattiin henkilöllä, jonka työtehtäviin kuuluivat muun muassa kutterinpurun ja turpeen levitys parsiin. Muita karjanhoitotöitä tekevä altistui hengittyvälle pölylle lypsytyötä tekevää enemmän. Kiinteiden näytteenottopisteiden aritmeettiset keskiarvot olivat samalla tasolla lypsyasemalla ja ruokintakäytävällä. Ruokintakäytävältä kerättyjen kiinteiden pisteiden näytteiden maksimipitoisuudet olivat kuitenkin suurempia kuin lypsyasemalta mitatut.

Ammoniakkipitoisuudet jäivät keskimäärin alle työntekijän ohjearvon $\left(\mathrm{HTP}_{8 \mathrm{~h}} 20 \mathrm{ppm}\right)$, mutta olivat samalla tasolla tai ylittivät maa- ja metsätalousministeriön asettaman eläinten ohjearvon (10 ppm). Aritmeettiset keskiarvot erityisesti syksyn 2002 mittauksissa olivat eri mittauspisteissä hyvin lähellä toisiaan (kuva 2), eikä eri ryhmien välillä ollut tilastollisesti merkittäviä eroja. Keväällä 2003 keskiarvopitoisuudet olivat nuorkarjan osalta suurempia kuin syksyllä. Pitoisuuksien vaihtelu oli kuitenkin melko suurta vaihteluvälin ollessa lypsyasemalla 0-18 ppm, ruokintakäytävällä 5-20 ppm ja nuorkarjatiloissa 6-23 ppm. Ritilän alla pitoisuus oli selkeästi suurempi kuin muissa mittauspisteissä. Suurimmat pitoisuudet nuorkarjan tiloissa ylittivät HTP-arvon. Eläinten ohjearvo ylittyi vähintään yhdessä mittauspisteessä kahdellatoista tilalla.

Hiilidioksidipitoisuus navettailmassa (kuva 3) alitti keskimäärin sekä työntekijän ohjearvon $\left(\mathrm{HTP}_{8 \mathrm{~h}} 5000 \mathrm{ppm}\right)$ että eläinten ohjearvon $(3000 \mathrm{ppm})$. Tilojen välinen vaihtelu oli kuitenkin suurta. Lypsyasemalla vaihteluväli oli 1200-3800 ppm, ruokintakäytävällä 900-3700 ppm ja nuorkarjantiloissa 1000-4000 ppm. Lietelantakanavassa ritilän alapuolella pitoisuus oli samalla tasolla kuin muissa kiinteissä mittauspisteissä. Eläinten ohjearvo ylittyi vähintään yhdessä mittauspisteessä neljällä tilalla. 


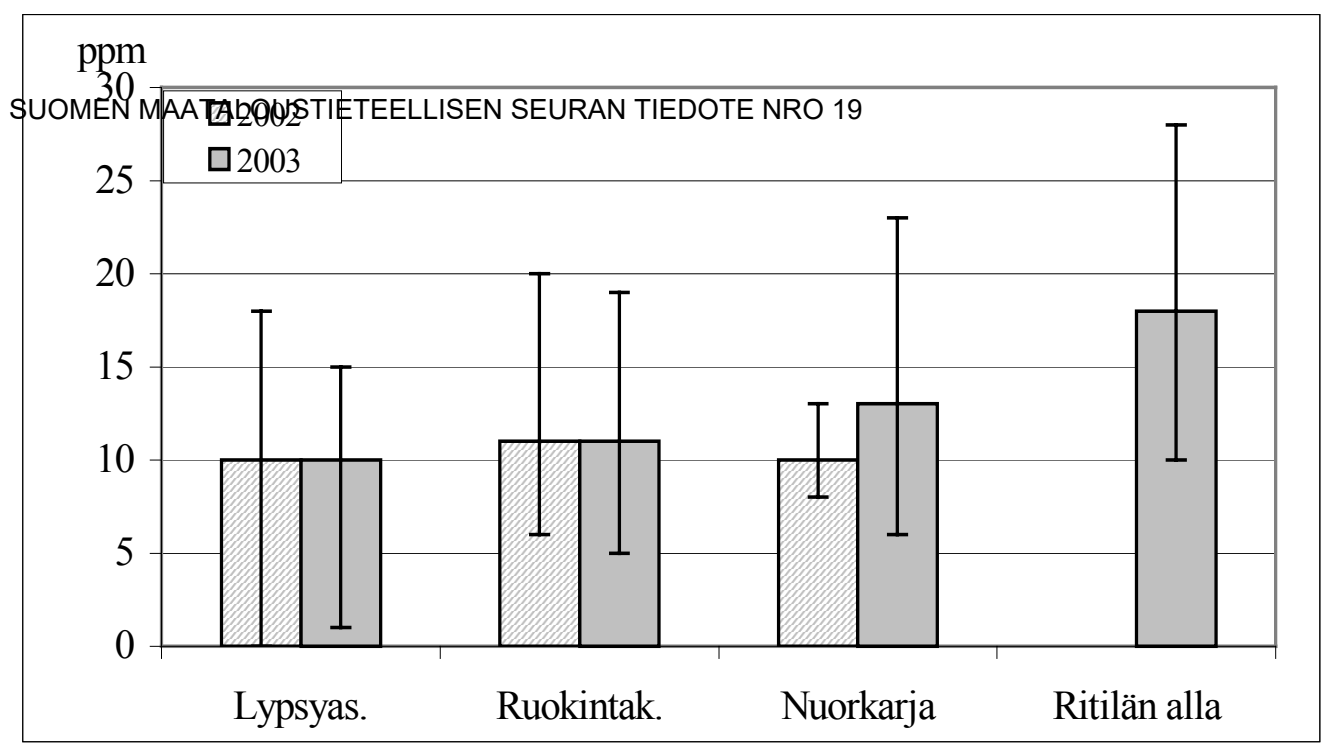

Kuva 2. Ammoniakkipitoisuuden aritmeettiset keskiarvot ja vaihteluvälit (ppm).

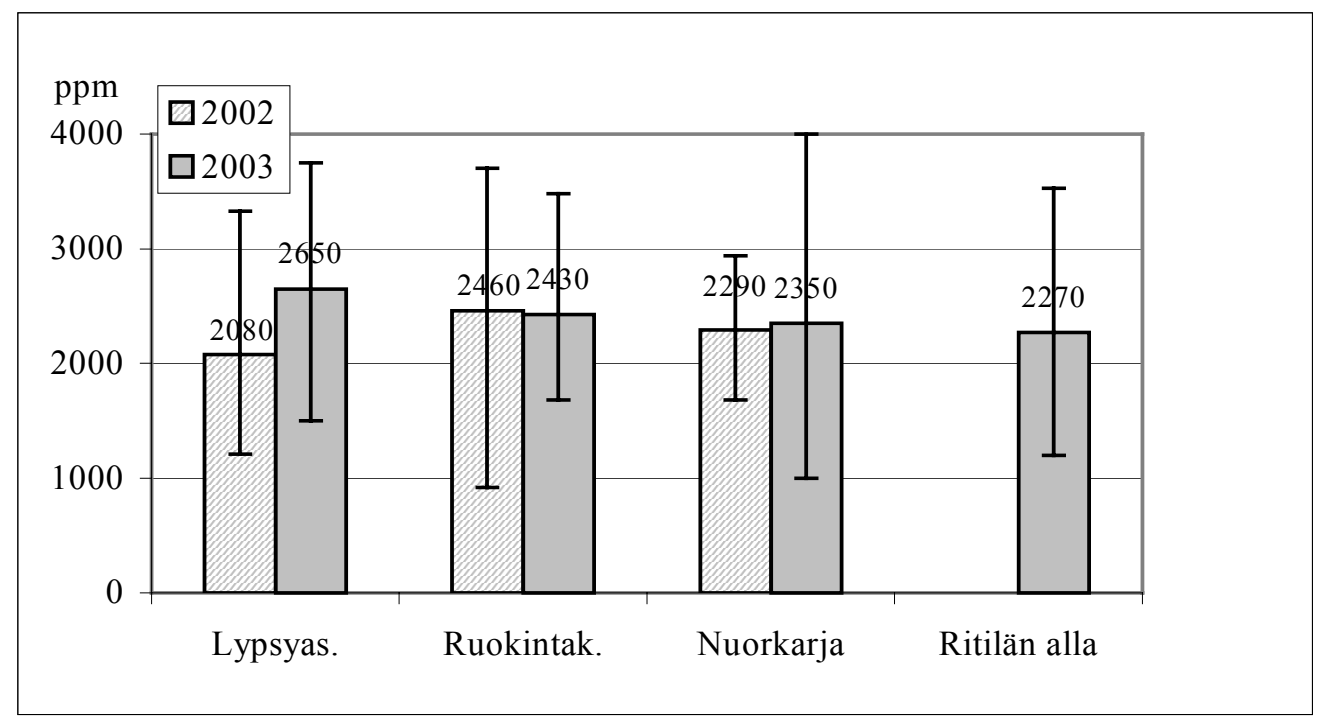

Kuva 3. Hiilidioksidipitoisuuden aritmeettiset keskiarvot ja vaihteluvälit (ppm).

\section{Johtopäätökset}

Tulosten perusteella pihatoissa työskentelevien hengittyvälle pölylle altistuminen oli vähäistä verrattuna orgaanisen pölyn 8 tunnin HTP-arvoon $5 \mathrm{mg} / \mathrm{m}^{3}$. Tulokset olivat samansuuntaisia kuin vuonna 1997 julkaistun osittain pihatoissa tehdyn tutkimuksen tulokset (Louhelainen ym. 1997). Uusissa pihatoissa pölyaltistuminen on huomattavasti pienempää kuin vanhoissa parsinavetoissa. Eroa selittävät muun muassa ruokinnassa tapahtuneet muutokset ja työmenetelmien koneellistuminen. Useimmissa pihatoissa lypsylehmien väkirehuruokinta oli täysin automatisoitu ja säilörehu tai ape jaettiin koneellisesti. Esikuivatun säilörehun yleistymisen myötä kuivan heinän käyttö ruokinnassa on vähentynyt tai lopetettu joillakin tiloilla kokonaan (Alakruuvi 1996). Näin oli tilanne myös tutkimuksen navetoissa. Tiloilla annettiin kuivaa heinää yleensä vain nuorkarjalle tai se jaettiin viimeisenä iltatöiden päättyessä. Pölyaltistumiseen vaikuttavat merkittävästi myös käytetyt kuivikkeet. Lypsykarjan kuivikkeina käytettiin yleensä purua ja jonkin verran turvetta. Aiemmin tyypillinen kuivike oli olki, mutta nyt sitä käytettiin vain muutamilla tiloilla vasikoiden kuivikkeena. Parilla tilalla lypsykarjalla ei ollut lainkaan kuivikkeita.

Karjanhoitotöitä tekevät altistuivat hengittyvälle pölylle enemmän kuin lypsytyöntekijät. Lypsytyöntekijä työskentelee pääosan työajastaan lypsyasemalla ja karjanhoitotöiden tekijä työskentelee kaikkialla pihatossa ja yleensä rehuvarastossakin. Karjanhoitotyötä tekevän työhön kuului muun muassa parsien kuivittaminen, mikä on yksi pölyävimmistä työvaiheista. 
Lypsyasemalta ja ruokintakäytävältä mitatut ammoniakki- ja hiilidioksidipitoisuudet olivat hyvin lähellä edellisessä pihattotutkimuksessa mitattujen arvoja (Louhelainen ym. 1997). Pitoisuudet eivät ylittäneet kyseisten kaasujen HTP-arvoja. Keskimäärin molempien kaasujen pitoisuudet olivat kuitenkin noin $50 \%$ HTP-arvoista, mitä voidaan pitää korkeana tasona työntekijän altistumista ajatellen. Ammoniakkipitoisuuksien keskiarvot olivat eläinsuojille asetettujen ohjearvojen tasolla tai yläpuolella (Maa- ja metsätalousministeriön asetus Nautojen pidolle asetettavista eläinsuojeluvaatimuksista 2002). Toisaalta yli puolella tiloista ruokintakäytävän, lypsyaseman tai nuorkarjan tilojen ammoniakkipitoisuus ylitti ohjearvon. Hiilidioksidin osalta keskiarvot alittivat maaja metsätalousministeriön asettaman ohjearvon, mutta muutamalla tilalla raja ylittyi niin lypsyasemalla kuin ruokintakäytävälläkin. Mitatut kaasupitoisuudet olivat samansuuntaisia kuin parsinavetoissa tehdyissä tutkimuksissa on havaittu (Kangas ym. 1987, Linnainmaa ym. 1993 ja Hanhela 1999). Huippupitoisuudet olivat kuitenkin parsinavettoja pienempiä (Kangas ym. 1987). Pihatoista mitatut pitoisuudet olivat pieniä verrattuna sikaloiden ja kanaloiden kaasupitoisuuksiin (Kangas ym. 1987).

Alapuolisen poistoilmanvaihdon on todettu alentavan ilman ammoniakkipitoisuutta katon kautta tapahtuvaan poistoon verrattuna. Pelkkään ala- tai yläpoistoon perustuvia ratkaisuja oli liian vähän tässä tutkimuksessa saman asian havainnoimiseksi. Kuitenkin alapoistovaltaisissa (yli puolet kokonaispoistosta alakautta) pihatoissa ammoniakkia oli ilmassa vähemmän kuin yläpuoliseen poistoon painottuvissa pihatoissa.

Kaasupitoisuuksien, lämpöolojen ja (katto)pinnoilta havaittujen kosteustiivistymien perusteella arvioituna ilmanvaihdon tehokkuus ei yleisesti ottaen ollut riittävällä tasolla. Hengittyvän pölyn ja mikrobien määrän vähenemisenä ilmenevä navettaympäristön puhdistuminen ei saa tukea haitallisten kaasujen osalta. Aiemmin parsi- ja pihattonavetoista mitattuihin ammoniakki- ja hiilidioksidimääriin verrattuna positiivista kehitystä ei tämän tutkimuksen mukaan ole havaittavissa, vaan altistuminen em. kaasuille on pysynyt samalla tasolla parikymmentä vuotta. Pölyjen määrän väheneminen ilmassa kertonee lähinnä rehu- ja kuivikemateriaalien käytössä sekä työmenetelmissä tapahtuneesta muutoksesta.

\section{Kirjallisuus}

Alakruuvi, A. 1996. Maatalouden työnormit: lypsykarjan hoitotyöt. Työtehoseuran maataloustiedote 10 (476). Hanhela, R. 1999. Työolosuhteiden vaikutus ammattiastman syntyyn karjanhoitotöissä. Väitöskirja. Kuopion yliopisto. Maatalousyrittäjien eläkelaitoksen julkaisut.

Kangas, J., Louhelainen, K. \& Husman, K. 1987. Gaseous health hazards in livestock confinement buildings. J Agric Sci Finland. 59:57-62

Linnainmaa, M., Louhelainen, K. \& Eskelinen, T. 1993. Effect of ventilation on ammonia levels in cowhouses. Am Ind Hyg Assoc J 54:678-682

Louhelainen, K. 1997. Farmers' Exposure to Dusts and Gases in Dairy Farms. Kuopion yliopiston julkaisuja C. Luonnontieteet ja ympäristötieteet 69. väitöskirja

Maa- ja metsätalousministeriön asetus Nautojen pidolle asetettavista eläinsuojeluvaatimuksista 6EEO/2002 